\title{
The Correlation Between Leadership Competency and Project Success in Construction Industry in Thailand
}

\author{
Tamer M. Alkadash ${ }^{*}$, Chayanit Nadam ${ }^{2}$ \\ * Assistant Professor, Gulf University. \\ ${ }^{2}$ Petroliam Nasional Berhad (PETRONAS), Malaysia.
}

\author{
Article Info \\ Article history: \\ Received 30 November 2019 \\ Received in revised form 11 February 2020 \\ Accepted 13 March 2020 \\ Published 01 April 2020
}

\begin{abstract}
This study's main goal is to highlight the significance of implementing competencies in a project environment and underline the attribute of key leadership that is critical for the project's success. The literature review focuses on determining leadership competencies: emotional intelligence, a leadership trait, and transformational leadership and its project success. This research is highlighted; the field of project management is more crucial; it involves integration across the functions with unexpected situation occurrences. This research is representing the view and correlation between leadership competencies such as emotional intelligence, a leadership trait, and transformational leadership with the leadership theories. The research model's methodology with the survey was developed and used the qualitative method to validate, evaluate, and analyze the data. The result of this research is to identify and define the correlation between leadership competencies and project success.
\end{abstract}

Keywords: Leadership Competency, Project Success, Emotional Intelligence, Leadership Trait, Transformation Leadership

\section{Introduction}

Leaders are a fundamental element for any organization to succeed in the present day of constant development and multi-tasking. Leaders who move the organization forward and fully take on large responsibilities for the team member and organization (Valliappan, et al., 2020). Project failure or success depends on the project managers who are committed to the success of the project. The project manager provides the resource to accomplish the objectives of the project and becomes the driving force for the project team, creating the vision of desirable outcomes (Jabbar \& Hussein, 2017). The project manager turns into a facilitator and a partner for the project team, together to provide support to accomplish the work necessary (Meng \& Boyd, 2017). The project manager provides the resource to accomplish the objectives of the project and becomes the driving force for the project team, creating the vision of desirable outcomes. Emphasizing the aforementioned information, it is important to question the correlation between productive performance or project success in project management and leadership competencies. The data collected and integrated with the literature theories will be produced by constructive facts and valuable analysis that can clarify the correlation between leader competencies and project success. Moreover, the result will be beneficial to the project manager or leader that able to apply in the real environment.

\section{Literature Review}

\subsection{Project Success}

Projects can be defined as the achievement of a specific objective with a specific period, beginning, and end dates. The project required a series of activities that need to be performed and consume resources that need to be used (Chakrabortty, Sarker, \& Essam, 2017). Macht et al. (2019) suggested that there is an orientation toward the long-term and higher goals such as marketability, completion, and profitability. Management of projects is needed in numerous business organizations. The trend is increasingly of the company to use the project to achieve their goals. However, there is a different definition of project success and unclear what things should be done or done to succeed. Hyväri (2006) mentioned that there is no well-defined project success in project management yet. Together, Albert et al. (2017) said that there is no agreement term of project success on the concept of project management. Project management has been identifying since the 1960 s without any discovery of any factor that could lead to project success. 
Recently, increasing researchers tend to focus more on the critical factor that could lead to project success or failure. Azhar et al. (2013) mentioned that a range of factors and variables could affect the potential to achieve the project's goals by various researchers. The following lists have been derived from the authors of Azhar et al. (2013) and Drucker (2002): project administrative, objectives, relations with the client, contracting, human parties, politics, and legal agreement. Together with Drucker (2002) mentioned the success of project factors in the following: profitability, third parties, competition, and implementation process, and market availability.

However, many researchers such as Zuo et al. (2018) mentioned that the main important factor is the critical project manager factor in terms of effective leadership skill, commitment, and the ability to coordinate. Alefari et al. (2017) also supported that the most important factors are leadership by being technically competent and being visionary. A study by Ahmed \& Bach (2014) stated clearly that leadership is required communication, commitment, and technical background as the main critical factor of project success. Contract with Hiatt (2006) indicated that project success is dependent on the life-cycle stages, not because of any critical factors. Nevertheless, several authors such as R. Ahmed \& Anantatmula (2017) and Gruden \& Stare (2018) noted that competencies and leadership style are the key success factors to a manager's success performance correlation with project management. The leadership style depends on the project life-cycle supported by R. Ahmed \& Anantatmula (2017).

\subsection{Leadership Theories}

According to Mango (2018), leadership theories can be stated into two types which are process theories and trait theories. The earliest study of theory, trait theory, is the first attempt on the study of leadership, which is about great man theory. As a result, the great man theory is the fundamental of other theories that keep representing, followed by the study and research of leaders' behaviors in a different leadership style. A few years later, Feyerherm \& Rice (2002) found out that the leadership style could cauterize into people-oriented and task-oriented, which is based on dichotomies and democratic. From this, the theory determined how the leader's style would suit or influence the situation, which is called the contingency theory or situational approach Thompson \& Glas $\varnothing$ (2018). However, according to Gottfredson \& Aguinis (2017), there is a minimum of sixty-six theories that explain the different theoretical leadership domains that have been used up to today. Transformational leadership is the theory that has been researched for the last thirty years which has been introduced to the audience by Burns (1978).

Burns (1978) claimed that many theories on leadership had been published, and we still unable to finalize. Thus, it is time to conclude the concepts of leadership. Zhang et al. (2020) mentioned that leaders are not about how much power they have to their subordinates, but it is how to fulfill a leader's desire which is including of how to influence, motivate or respond to the subordinates to act to achieve the goals with the moral and value manners.

Project management is supported by various theories, including the leadership function management that is authenticated by various theories. Most of the behavioral theories of leadership focused on discovering the constant relationship between the group performance and leadership behaviors; the contemporary theories emphasized the significance of situational factors, i.e., leader's intelligence, stress level, follower's trait, and job description (Maqbool, Sudong, Manzoor, \& Rashid, 2017). There is some of the important leadership theory in the following;

\section{Transformational and Transactional Theory}

Transforming leadership is the relation between elevation and mutual stimulation that converts subordinates or followers to leaders (Budur \& Poturak, 2020). Transforming leadership happens when there is engagement from one or more with others, and that is shown the special person that different from common people or to a higher level of morality and motivation. Bums has drawn transformational leadership that he has worked into the type of leadership that has been said that the power of transforming leadership is more on business or executive leadership and heroic leadership, which is more different from charismatic leadership (Gottfredson \& Aguinis, 2017). However, Bernard Bass developed the concept of original transforming leadership into the concept of transforming "leadership in performance and leadership" beyond expectation to "transformational leadership" where leader transforms their subordinate and the direction of influence in on-way; unlike Bums who see it as potentially a two-way process (Bass, 1990).

Transactional leadership has been the traditional model of leadership with its roots from the business or organization perspective in the bottom line (Bass, Avolio, Jung, \& Berson, 2003). Turner \& Lloyd (2008) support the theory of Avolio that the principle-centered leadership' suggests that transformation leadership is more focusing on the top line and offers a contrast between the two in the following table.

Table 1. Transformational Leadership versus Transactional Leadership

\section{Transformational Leadership}

- The concern with values, ethics, morals, and purposes

- $\quad$ Surpass daily affair
Transactional Leadership

- The concern with position, perks, power, and politics

- Delay in the daily affair 


\begin{tabular}{lll}
\hline \multicolumn{1}{c}{ Transformational Leadership } & \multicolumn{2}{c}{ Transactional Leadership } \\
\hline - Focus on strategy and mission & Focus on the tactical issue \\
Release human potential, develop and identify new & - Rely on human relations to human interaction \\
talent & - Support system and structure that reinforce \\
Align internal system and structure to reinforce \\
$\begin{array}{l}\text { overarching goals and values } \\
\text { Design job to make them challenging and } \\
\text { meaningful }\end{array}$ & $\begin{array}{l}\text { Fulfill the expectation roles by striving to work } \\
\text { efficiently and effectively with the current system }\end{array}$ \\
\hline
\end{tabular}

Afsar et al. (2017) agreed that both leadership is important as transactional leadership will remain the organizational model for organizations, and people who have not to encourage the transformational role needed to meet the challenges of any changes. Hiatt (2006) mentioned that transformational leadership aims to transform organizations and people to change their hearts and minds for understanding, enlarging insight and vision, clarifying purpose, and making behavior congruent with values, principles, and beliefs.

Conger (1999) referred to Avolio and Bass that transformational leaders show the behaviors associated with five transformational styles, shown in Table 2 .

Table 2. Transformational Leadership Styles

\begin{tabular}{|c|c|}
\hline Transformational Style & Leader Behavior \\
\hline a) Idealized Behaviors & $\begin{array}{l}\text { - } \text { Consider the ethical and moral of decision } \\
\text { - } \quad \text { To focus on how trust in each other is important } \\
\text { - } \quad \text { To talk about their important beliefs and values } \\
\text { - } \quad \text { Always exciting about new possibilities }\end{array}$ \\
\hline b) Inspirational Motivation & $\begin{array}{l}\text { - To provide an exciting image of what is essential to consider } \\
\text { - } \quad \text { Confidence of goals will be achieved } \\
\text { - } \quad \text { Stand on controversial issues } \\
\text { - } \quad \text { Compel vision of the future }\end{array}$ \\
\hline c) Intellectual Stimulation & $\begin{array}{l}\text { - Looking for a different perspective when solving the problem } \\
\text { - } \quad \text { Encourage ideas which never been questioned before and non-traditional } \\
\text { thinking } \\
\text { - Re-evaluate the critical assumptions if it's appropriated }\end{array}$ \\
\hline d)IndividualizedConsideration & $\begin{array}{l}\text { - } \\
\text { - } \\
\text { Provist others to find and develop strengths } \\
\text { - } \\
\text { Listen to others } \\
\text { Realize that an individual has different aspiration, abilities, and needs from } \\
\text { others }\end{array}$ \\
\hline e) Idealized Attributes & $\begin{array}{l}\text { - To create others' respect } \\
\text { - } \quad \text { Sacrifices for others' benefit } \\
\text { - } \quad \text { Show a sense of competence and power }\end{array}$ \\
\hline
\end{tabular}

Budur \& Poturak (2020) wrote that transformational leadership is the stage or process for leaders to take action and create awareness of what is important and right, associate and go beyond 'own self-interest' for beneficial of the team, organization, and society. Hiatt (2006) said that the transformational leader is proactive uniquely and differently. Leaders endeavor to optimize development such as attitudes, motivation, value, and ability (Hyväri, 2006). However, Epstein et al. (2010) mentioned that seven key competencies of transcendent leaders from the notion of transformational leadership which able to engage the emotional support of subordinates, from this to generate the effectively transcend change.

\subsection{Key Leadership Competencies}

\section{Leadership Trait}

Leadership began in the 1800s. It defined the great leader who was able to possess something out of ordinary, inborn characteristic; naturally, that makes them above the rest. Turner \& Lloyd (2008) said that leader always has some special characteristic that is different from common people. However, several authors supported the idea that effective leaders are different from other people, such as leadership motivation, achievement in motivation, tenacity, energy, and ambition.

Leadership is one of the behaviors that impose the people to formulate and motivate to deliver the work or project by following the organizational goal. In the organization, people are considered the important asset of the organization, together with the leader who plays a vital role in the strategic management and decision making to ensure effectiveness and organization success (Gottfredson \& Aguinis, 2017). Khator (2012) explained that a leader should be supportive and the guidance to their subordinates. The leader should treat everyone equally and appreciate everyone's involvement. 
Zhang et al. (2020) mentioned that the leader has the responsibility to create strong relationships with the entire organization, and it is the commitment of the leader to achieve the strategic vision.

A leadership review by Barbuto \& Burbach (2006) has a controversial and long history; as a result, there is no guarantee of the leadership traits that could make them successful. Leadership is a complex process with its standard, competencies, or qualities that can capture and deliver the leader or organization and success (Hyväri, 2006). The leader is prompted as the sole source of "leadership" as they need to act as a visionary, energizer, and catalyst with a set of tools such as communication, people management, decision making, problem-solving, which can be applied across context and situations. The soft skills are also needed for the dealer to convey the excellent message, information processing, delivery skills, customer services, project management, and political acumen and proven business. Moreover, a leader is emphasized on the important value, i.e., integrity, honestly, valuing diversity, and trust (Zuo et al., 2018).

\section{Emotional Intelligence}

The effective leader influences their subordinates to the project success or desired goals. Ayman \& Lauritsen (2018) showed that several organizational contingencies and multi-personal with interpersonal behaviors had influenced the concept of leadership. Mango (2018) mentioned that the leadership style has an impact on organizational performance or its effectiveness. The leadership style is fundamental in the organization's culture on how the job has been done and how people's relationship to perform the job is the aspect of human behavior. Acquiring the appropriate leadership style would be the major factor for the leader to achieve.

According to Badri-Harun et al. (2016), leadership performance is linked to emotional intelligence (EI) that has been described as a person could affect or other emotions. Bagshaw (2000) mentioned that intrapersonal and interpersonal intelligence are different and unique from the logical type that has been recognized as general intelligence or IQ.

EI includes four components which are (1) self-management is to manage emotional reaction, and ability to be aware of other's emotions in all situation with all people, (2) self-awareness is the ability to manage other's response to people and specific situation or the ability to perceive other's emotions and aware of them, (3) relationship management is the ability to aware on own and other emotions to manage interactions and (4) social awareness successfully is the ability to identify the emotion of people and understand the effect of those emotions.

\section{Leadership Style and EI}

EI is how to manage others' emotions in a position, and productive style or EI is the range of non-cognitive competencies, capabilities, and skills that influence others' ability to succeed in coping with pressures and environmental demands (Blaskovics, 2014). EI is important in leadership from the management perspective. Researchers found that EI is required for a leader as it is significant in the circumstance of the organization (Gündemir, Carton, \& Homan, 2019). Therefore, EI has been explored and reviewed clearly that it focused on values, behavior, and traits that are basically for leadership competency. Raisiene (2014) used the EI concept to control or understand one's own or other's emotions to guide the way one thinks and acts. Zia-ur-Rehman \& Zia (2020) mentioned that EI is the organizational framework in which the workplace competency has the EI as the competency concept.

However, several types of research have been conducted and explained that those who were primarily strong in EI have the potential to be a success than those who have experience or strong in IQ. Harper and Jones-Schenk (2012) mentioned that a high EI leader would be more productive than who with the low EI up to 20\%. Also, Ricketts (2009) conducted a study from 358 managers across Johnson \& Johnson to determine the specific leadership competencies between the person who has high performance and low performance. As a result, it shows that the person who has high performance had significantly more EI as their competencies than did a low performance. Zia-ur-Rehman \& Zia (2020) supported other researches that EI significantly influences the performance of a leader, a leader who has a high level of EI will have a greater effect on the organization or tend to deliver project success more than a leader who has a low level of EI.

\section{Transformational Leadership}

Transformational leadership was formulated by Burns (1978) on the basis of a qualitative research model on political leadership, which stated that leaders and subordinates raise each other to a higher level of motivation and morality. Batool (2013) claimed that leaders needed moral principles, fairness, harmony, morals, and equality to lift subordinates' consciousness. Giritli, Öney-Yazıcı, Topçu-Oraz, and Acar (2013) pointed out that Bass (1985) proposed a transformational leadership theory based on Burns's ideas. The theory is that there are two types of leadership. Bass viewed transactional leadership as a reward and an exchange of achievement. Transformational leadership is said to have an effect on its subordinates, such as admiration, respect, trust, and loyalty toward the leader and motivate the subordinates to perform the job. Leaders transform their subordinates (1) to avoid self-interest in teams and organizations, (2) to energize higher needs, and (3) as a result of tasks. Transforming and motivating subordinates by making them aw are of 
their importance. The theoretical point is the use of transformational leadership from transactional leadership to motivate subordinates to positive performance (Raisiene, 2014).

\subsection{Project Success}

The project's success is not a fixed goal. Müller and Jugdev (2012) reviewed the changing understanding of what constitutes project success: in the 1980s, there was a strong focus on using appropriate tools and methods. At that time, the list included the competence of project managers, not competition. They set the right criteria for success and then identified successes that would help the project succeed. In meeting those standards, they discuss the selection of tools and technologies based on one of the successful case studies. The traditional criteria for project success to achieve business outcome starts with the planning for the new project (usually new products or services), and finally determined by time or cost, quality, but not including the competence of the project manager. However, many management paradigms incorporate within project management, such as portfolio management and risk management. The relationship between project manager success and leadership effectiveness has been identified in previous studies by using multiple criteria measurement.

\subsection{The Impact of Leaders on Organization}

Leadership research has been conducted in different views, such as the impact of transformation leading to the subordinates or how training could increase the transformational leadership behavior. Hyväri (2006) concluded that transformational leadership is influencing the team member in the organization, such as individual or team performance, the organization's culture, and characteristics or behavior of staff in the organization. From this, positive influence will able to provide a positive organization's performance as the results (Hair Jr, 1995). Dulewicz \& Higgs (2004) found that the subordinates are more effective in terms of performance, perception, feeling with a positive impact when they have a high number and quality of a transformational leader. Hyväri (2006), supported by his research, also mentioned that transformational leadership would create job performance and job satisfaction by sharing the leadership to create a strong relationship among the people in the organization. However, the leader needs to be a good sample of the person, inspiring the subordinates, influencing them to perform the job as required with the motivation, and committing to the goals (Chaturvedi, Rizvi, \& Pasipanodya, 2019; Alkadash, 2020). From this, it will avoid any conflict between staff, leaders, and organizations as transformational leadership has been created to enhance the satisfaction and trust in the team. There are several researchers found that to develop transformational leadership, especially on the intellectual stimulation, will improving the feeling or perception between subordinates and managers as the subordinates feel on the strong relationship and commitment to the organization (reference).

Based on the study problem and objectives has been discussed above, the hypothesis of this research will be the following subjects;

- H1: There is a significant relationship between emotional intelligence and project success.

- H2: There is a significant relationship between leadership traits and project success.

- H3: There is a significant relationship between transformational leadership and project success.

\section{Methods}

Researchers used quantitative research because quantitative research is more focused on the number of things in which the data is in the form of numeric, and the analysis will involve quantification and counting to get the result. Large results of data and statistical techniques will be used to analyze the data, which often provide the macro view as it involves large samples.

Hair Jr (1995) supports using qualitative research as most researchers usually survey to capture data which by using this method as less resource-intensive, more cost-effective, and can capture over time which is not influenced by the change of interviewer behavior. Feyerherm \& Rice (2002) mentioned that the description in terms of statistics, multiple regression analysis, and correlation analysis which is provided the value to the study by presenting dependent and independent variables. Multiple regression and correlation analysis techniques will be applied to determine the hypothesis relationships between the variables. To use correlation analysis techniques will be classified as the level of amount, direction, and relationships between multi-variables.

\section{Survey Instrument}

The researcher used the data that has been gathered from previous studies. The survey instrument has been modified to suit the purpose of the research. The creation of a custom instrument is supported by the study, which will measure the independent and dependent variables that have been already identified in the research questions. Based on Dong (2003), the question instrument model was the incorporation of both validated LPI-Self and established. Alongside similarly 
formatted questions created in support of this study. The survey instruments for this research were developed which is based on the previous studies:

\section{- Emotional Intelligence}

Four questions will be conducted to measure the emotional intelligence variable. There is a 5 Likert scale which is started from 1 that representative of very relevant, two representatives of relevant, three representatives of neutral, four representatives of irrelevant, five representatives of very irrelevant. The question has been developed by Hair Jr (1995).

\section{- Leadership Trait}

Six questions will be conducted to measure the leadership traits variable. There is a 5 Likert scale which is started from 1 that representative of very relevant, two representatives of relevant, three representatives of neutral, four representatives of irrelevant, five representatives of very irrelevant. The question has been developed by Hair Jr (1995).

\section{- Transformational Leadership}

Five questions will be conducted to measure the emotional intelligence variable. There is a 5 Likert scale which is started from 1 that representative of very relevant, two representatives of relevant, three representatives of neutral, four representatives of irrelevant, five representatives of very irrelevant. The question has been developed by Hair Jr (1995).

\section{- Project Success}

Five questions will be conducted to measure the project success variable. There is a 5 Likert scale which is started from 1 that representative of very relevant, two representatives of relevant, three representatives of neutral, four representatives of irrelevant, five representatives of very irrelevant. The question has been developed by Hair Jr (1995).

\section{Population \& Sampling}

The respondents are managers working in the construction industry in Southern Thailand. One hundred sixty-nine manager respondents to complete the survey were the researchers followed a random sample to save time and money, which was considered a limitation of the study. The questionnaire emailed to respondents as a study show technology project success. Google docs have been used for creating an online survey. Then, to email to the shortlisted respondents of the available email from the public on the company's website. The hard copy or printed survey was also distributed in hard copy for some employees at the offices in Songkhla and Nakorn Sritammarad, Southern of Thailand. The structure of questionnaires will be in a formal format and standardize format that has been distributed and asked all the respondents for two weeks of duration. The questionnaire is required for two weeks for the questionnaire collection and analy sis of the data. Using SPSS 22.0, the researchers run the required tests to analyze the data at hand.

\section{Results}

\subsection{Data Screening}

Questionnaires are an important tool to conduct the data and findings of the research. For the survey, 195 questionnaires have been distributed to the profession in the construction industry companies in Thailand. As a result, 169 or $96.6 \%$ of questionnaires from 175 questionnaires could be used and valid for analysis. The descriptive statistic that includes percentage and frequencies was used to present the sample's main characteristics; table 1 set out a summary of respondents' profiles. It was observed that the majority of the sample are male (\%76.5). Altogether (\%38.7) of all respondents aged 31 - 40 years old. Overall, \%76.4 of the respondent's education level background shows they hold a bachelor's degree. Altogether $\% 37$ of all respondents' experience from 5 - 10 years old. Therefore, this sample can be considered suitable for examining the research issue of this study.

Cronbach Alpha value for the first independent variable emotional intelligence with the value of 0.819 , which is considered as the acceptable coefficient of reliability, the next independent variable is leadership trait with the value of 0.843 , which is the acceptable coefficient of reliability, the next independent variable is transformational leadership with the value of 0.798 which is the acceptable coefficient of reliability. The dependent variables are Project success with the Cronbach's Alpha of 0.821, which is an acceptable coefficient of reliability. 


\subsection{Reliability (Cronbach's Alpha)}

Concerning Dong (2003), Cronbach's Alpha shows how do the items in a set are positively related to each other in the reliability coefficient. According to the reliability test result, the closer the Cronbach's Alpha is to 1, the higher the internal consistency reliability. If the reliability is less than 0.60 , then it is considered poor. Meanwhile, if it is in the range of 0.70 , it is considered acceptable. As for those more than 0.80, is it considered good (Dong, 2003)?

Table 3. Reliability Test

\begin{tabular}{l|l|l|l}
\hline Variable & No of Item & Cronbach's Alpha & Remarks \\
\hline Emotional Intelligence (IV) & 4 & 0.819 & Good \\
\hline Leadership Trait (IV) & 6 & 0.843 & Good \\
\hline Transformational Leadership (IV) & 5 & 0.798 & Good \\
\hline Project Success (DV) & 5 & 0.821 & Good \\
\hline
\end{tabular}

According to the table above, the analysis shows that the Cronbach Alpha value for the first independent variable emotional intelligence with the value of 0.819 , which is considered as an acceptable coefficient of reliability, the next independent variable is leadership trait with the value of 0.843 , which is the acceptable coefficient of reliability, the next independent variable is transformational leadership with the value of 0.798 which is the acceptable coefficient of reliability. The dependent variables are Project success with the Cronbach's Alpha of 0.821, which is an acceptable coefficient of reliability.

\subsection{Descriptive Analysis}

The descriptive analysis is being used to indicate the general statistic description of the independent and dependent variables in this research study. The statistics such as means, minimum value, maximum value, standard deviations, and variance are tested for the interval-scaled of the independent and dependent variables by using SPSS V.20.

\section{Emotional Intelligence}

The questions tried to evaluate the respondent's results regarding self-awareness, self-control, motivation, and charism. The data results would verify, validate, and support factors of project leadership that are critical when managing projects. Table 4 illustrates the results of Emotional Intelligence.

Table 4. Emotional Intelligence Descriptive Analysis

\begin{tabular}{l|c|c}
\hline \multicolumn{1}{c|}{ Statement } & Mean & Std. Deviation \\
\hline $\begin{array}{l}\text { 1. The leader is self-aware of his or her feelings and can recognize and control } \\
\text { them* }\end{array}$ & 2.479 & .6181 \\
\hline 2. The leader uses his/her self-control to increase project success* & 2.456 & .5972 \\
\hline $\begin{array}{l}\text { 3. The leader uses motivation to the team group and drives energy to achieve } \\
\text { clear results and make an impact on the project* }\end{array}$ & 2.414 & .6409 \\
\hline \begin{tabular}{l} 
4. The leader uses vision and imagination* \\
\hline
\end{tabular}
\end{tabular}

Descriptive analysis result for emotional intelligence, the highest value come emotional intelligence statement No. 4 $($ mean $=2.651$, Std. Deviation= 0.758), No. $1($ mean= 2.479, Std. Deviation=0.618), then follow dimension No. $2($ mean= 2.456, Std. Deviation= 0.597), then follow dimension No. 3 which is the lowest $($ mean= 2.414, Std. Deviation=0.641).

\section{Leadership Trait}

Table 5 shown descriptive analysis result for variable leadership trait, The highest value come to leadership trait statement no. 3 (mean value $=2.521$, Std. Deviation= 0.725), then follow statement no.2 $(\mathrm{mean}=2.509$, Std. Deviation= 0.717 which is same with statement no. 4 (mean value $=2.509$, Std. Deviation $=0.725)$, follow statement no.6 (mean value $=2.408$, Std. Deviation= 0.759) and the lowest value goes to statement no.5 (mean=2.308, Std. Deviation=0. 690).

The questionnaires underline the significance of project leadership traits. These questions evaluated the results regarding the following leadership criteria: good listener, open mind, effective delegation of tasks, hard worker, the inspiration of teamwork, flexibility, ethical behavior, vision, strategic view, and creativity. These sets of questions' objective was to allow the research to validate and investigate the participant's answers associated with traits that are necessary for project managers. Simultaneously, to analyze how project managers who participated in the survey interpreted successful leadership competencies concerning project success. 
Table 5. Emotional Leadership Trait Descriptive Analysis

\begin{tabular}{l|c|c}
\hline \multicolumn{1}{c|}{ Statement } & Mean & Std. Deviation \\
\hline $\begin{array}{l}\text { 1. The leader employs strategic perspective, being aware of the wider issues identifies } \\
\text { opportunities and threats* }\end{array}$ & 2.320 & .5913 \\
\hline $\begin{array}{l}\text { 2. The leader always works with ethics and with the responsibility to the society and the } \\
\text { organization* }\end{array}$ & 2.509 & .7165 \\
\hline $\begin{array}{l}\text { 3. The leader organization resource and coordinates them efficiently and effectively* } \\
\text { 4. The PM delegate tasks and gives autonomy also encourages team group to take new } \\
\text { challenges, to solve problems and develop their proper ideas* }\end{array}$ & 2.521 & .7245 \\
\hline $\begin{array}{l}\text { 5. The leader shows a commitment to greatness to obtain the objectives and implement } \\
\text { decisions, personal and to the team }\end{array}$ & 2.509 & .7247 \\
\hline $\begin{array}{l}\text { 6. The leader analysis and judge in terms of gathering relevant information from a wide range } \\
\text { of sources, probing the facts, identifying advantages and disadvantages* }\end{array}$ & 2.408 & .6901 \\
\hline
\end{tabular}

\section{Transformational Leadership}

Table 6 shown descriptive analysis result for variable transformational leadership, the highest value come to transformational leadership dimension no.4 (mean= 2.586, Std. Deviation= 0.752), then follow dimension no.4 (mean= 2.586, Std. Deviation = 0.752), then follow dimension no.2 $($ mean=2.503, Std. Deviation $=0.7490)$, follow dimension no.3 $($ mean $=2.456$, Std. Deviation= 0.816) and the lowest dimension no.1 $($ mean=2.373, Std. Deviation $=0.670)$.

Table 6. Transformational Leadership Descriptive Analysis

\begin{tabular}{l|l}
\hline Statement & Mean \\
\hline $\begin{array}{l}\text { 1. The leader has an open view of the situations, also takes into consideration the needs and } \\
\text { perceptions of the team members. } *\end{array}$ & 2.373 \\
\hline $\begin{array}{l}\text { 2. The leader increase team members awareness, changing a viewpoint based on the } \\
\text { understanding of their position and the recognition* }\end{array}$ & 2.503 \\
\hline $\begin{array}{l}\text { 3. The leader arrives at a decision and proposes solutions to problems and challenges, on } \\
\text { his/her own, also with team members }\end{array}$ & 2.456 \\
\hline $\begin{array}{l}\text { 4. The leader encourages team members to work together also to take the challenge and } \\
\text { demanding tasks, roles, and responsibilities* }\end{array}$ & .7490 \\
\hline \begin{tabular}{l} 
5. The leader uses creativity to solve problems and to create solutions* \\
\hline
\end{tabular} & .7520 \\
\hline
\end{tabular}

\section{Project Success}

Table 7 shown descriptive analysis result for variable project success, The highest value come to project success statement no.3 (Std. Deviation=0.744, mean value $=2.639)$, then follow statement no.2 $($ Std Deviation=0.732, mean= 2.462 ), then follow statement no.5 (Std. Deviation= 0.607, mean value $=2.456)$, follow statement no.4 (Std. Deviation= 0.6295 , mean value $=2.355)$ and the lowest value goes to statement no.1 $($ Std. Deviation=0.683, mean=1.284).

Table 7. Project Success Descriptive Analysis

\begin{tabular}{l|l}
\hline Statement & Mean \\
\hline $\begin{array}{l}\text { 1. Completing the Project on time according to the time plan established* } \\
\text { 2. Completing the Project on cost according to the cost plan established* }\end{array}$ & 2.284 \\
\hline $\begin{array}{l}\text { 3. Completing the Project with higher standards of quality according to the quality plan } \\
\text { established* }\end{array}$ & 2.462 \\
\hline $\begin{array}{l}\text { 4. Completing the Project in terms of product success according to the plan established* } \\
\text { 5. Establishing interrelation with all stakeholders of the project* }\end{array}$ & 2.639 \\
\hline
\end{tabular}

\subsection{Correlation Analysis}

Spearman correlation coefficient to study the correlations between the leadership competencies (emotional intelligence, a leadership trait, and transformational leadership) and project success, and the results shown through the following tables: 
Table 8. Correlation Matrix Result of the variables

\begin{tabular}{|c|c|c|c|c|c|}
\hline & & EI & IV2 & IV3 & DV \\
\hline \multirow{3}{*}{ EI } & Pearson Correlation & 1 & $.678 * *$ & $.638 * *$ & $.721^{* *}$ \\
\hline & Sig. (2-tailed) & & .000 & .000 & .000 \\
\hline & $\mathrm{N}$ & 169 & 169 & 169 & 169 \\
\hline \multirow{3}{*}{ IV2 } & Pearson Correlation & $.678 * *$ & 1 & $.604 * *$ & $.628 * *$ \\
\hline & Sig. (2-tailed) & .000 & & .000 & .000 \\
\hline & $\mathrm{N}$ & 169 & 169 & 169 & 169 \\
\hline \multirow{3}{*}{ IV3 } & Pearson Correlation & $.638 * *$ & $.604 * *$ & 1 & $.597 * *$ \\
\hline & Sig. (2-tailed) & .000 & .000 & & .000 \\
\hline & $\mathrm{N}$ & 169 & 169 & 169 & 169 \\
\hline \multirow{3}{*}{ DV } & Pearson Correlation & $.721 * *$ & $.628 * *$ & $.597 * *$ & 1 \\
\hline & Sig. (2-tailed) & .000 & .000 & .000 & \\
\hline & $\mathrm{N}$ & 169 & 169 & 169 & 169 \\
\hline
\end{tabular}

Table 6 shows the relationship between (emotional intelligence, a leadership trait, and transformational leadership) against project success.

\subsection{Multiple Regression Testing}

The multiple regression test inducted R2 $=0.571$ and Adjusted R2 $=0.456$. It means there is a good correlation between the dependent variable "Project success" and the independent variables "Emotional intelligence, a Leadership trait, and transformational leadership. The value of $F$ scores of the model shows that $(F=73.43)$, it means there is a significant correlation at the significance level $(0.05=\alpha)$ between (Emotional intelligence, a Leadership trait, and transformational leadership) on Service quality construction industry in Thailand. Emotional intelligence Variable demonstrate there is a positive correlation on Project success $(\mathrm{B}=.507, \mathrm{~T}$ value $=6.269$ and sig. level .00$)$ followed by organization commitment variable demonstrate there is a positive correlation on Project success $(\mathrm{B}=.196, \mathrm{~T}$ value $=2.777 \mathrm{and}$ sig. level .006) and Emotional intelligence variable there is a no correlation on Project success $($ Beta $=.178, \mathrm{~T}$ value $=2.485$ and sig. level .014). See table 7

\section{Conclusion, Discussion, Suggestion for Future Research}

Leadership is a key element to deliver the project's success or achieve a particular objective. The direction and action that a leader decides to take are extremely critical for the team member's performance and the project toward the achievement or failure of the organization. Everyone has different personalities, mindsets, and backgrounds. Thus, leaders should become mindful that every individual is encouraged and driven by a different factor.

The aim to achieve effective leadership in project success and project management is a long journey that is filled with challenges and obstacles, but at the same time, it is full of remarkable experiences and great opportunities.

This study's results contribute to the body of knowledge in the areas of principal leadership performance with the leadership trait, emotional intelligence, and transformational leadership. The finding of this research supports the existing research that postulated that three main leadership competencies have a significant effect on leadership performance in the business.

Implementation of emotions intelligently in any organization by a leader to be effective and efficient plays a vital role in the leader effectively. There are so many studies that reflect that Emotional Intelligence also has impacts on organizational goals. Our study reflects that emotional intelligence can help reduce stress, improve performance and sense of achievement by motivating the subordinates within the organization, and enhance the employees' productivity to meet organizational end goals ethically by putting positive impacts on society as a whole.

The study indicates that three main leadership competencies, which are leadership trait, emotional intelligence, and transformational leadership, have a significant effect on a principal's leadership performance. Additional research is needed to validate the findings of this study.

Further research should focus on leadership traits, emotional intelligence, and transformational leadership in other sectors and other states. Further research could also focus on leadership performance categories of community leadership and cultural competence, categories on which three main leadership competencies had no significant effect on this study. Further research also needs to be conducted to see if a link does exist between principals' leadership competencies and increasing leader achievement. 
Moreover, the topic is to find out the correlation between leadership competencies (emotional intelligence, a leadership trait, and transformational leadership) and project success. Further research could focus on the correlation of project success with other leadership competencies or validate more on the variable of emotional intelligence, a leadership trait, and transformational leadership. As those three main variables, several elements such as emotional intelligence Are developed by several competencies, i.e., communication, discipline, stress, responsibility, and working environment. On the other hand, future research could focus on how a leader's emotion intelligently to achieves the target in today's play's rapidly changing environment due to technological and globalization advancement.

There is some limitation to complete the research as the respondents are only from the construction industry and in Thailand. Thus, the opinion and view might influence by the culture or the background of respondents. Moreover, the data collection approach is only focused on the professional level, not inclusive of their subordinates. Thus, the data and result might result from only the leader's point of view. Together with the time constraint, the questionnaires were distributed only for two weeks which might not enough time for the respondent to answer and complete the questionnaires. Thus, only 169 respondents for this research study. From this, the future researcher could extend the finding by covering the point of view from subordinates and other groups of respondents or in other industries.

\section{References}

Afsar, B., Badir, Y. F., Saeed, B. Bin, \& Hafeez, S. (2017). Transformational and transactional leadership and employee's entrepreneurial behavior in knowledge-intensive industries. The International Journal of Human Resource Management, 28(2), 307-332.

Ahmed, A., \& Bach, C. (2014). Major traits/qualities of leadership. International Journal of Innovation and Scientific Research, 3(1), 47-53.

Ahmed, R., \& Anantatmula, V. S. (2017). Empirical study of project managers leadership competence and project performance. Engineering Management Journal, 29(3), 189-205.

Alkadash, T. (2020). Mediating Role between Authentic Leadership, Organizational Commitment on Talents Turnover Intention: in Palestine Higher Education. TEST Engineering \& Management, 83, 5320-5341.

Alkadash, Tamer M, Almaamari, Qais, Al-Absy, Mujeeb, \& Raju, Valliappan (2020). Theory of Transformational Leadership towards Employee Performance as Sequence of Supply Chain Model: The Mediating Effect of Job Autonomy in Palestine Banks during COVID-19 Pandemic. International Journal of Supply Chain Management, 9 (5), 256-263.

Albert, M., Balve, P., \& Spang, K. (2017). Evaluation of project success: a structured literature review. International Journal of Managing Projects in Business.

Alefari, M., Salonitis, K., \& Xu, Y. (2017). The role of leadership in implementing lean manufacturing. Procedia CIRP, 63, 756-761.

Ayman, R., \& Lauritsen, M. (2018). Contingencies, context, situation, and leadership.

Azhar, A., Ikram, S., Rashid, S., \& Saqib, S. (2013). The role of leadership in strategy formulation and implementation. International Journal of Management \& Organizational Studies, 1(2).

Badri-Harun, A., Zainol, M. R., Amar, A., \& Shaari, Z. H. (2016). Emotional intelligence as mediator between leadership styles and leadership effectiveness: A theoretical framework. International Review of Management and Marketing, 6(1).

Bagshaw, M. (2000). Emotional intelligence-training people to be affective so they can be effective. Industrial and Commercial Training.

Barbuto, J. E., \& Burbach, M. E. (2006). The emotional intelligence of transformational leaders: A field study of elected officials. The Journal of Social Psychology, 146(1), 51-64.

Bass, B. M. (1985). Leadership: Good, better, best. Organizational Dynamics, 13(3), 26-40.

Bass, B. M. (1990). From transactional to transformational leadership: Learning to share the vision. Organizational Dynamics, 18(3), 19-31.

Bass, B. M., Avolio, B. J., Jung, D. I., \& Berson, Y. (2003). Predicting unit performance by assessing transformational and transactional leadership. Journal of Applied Psychology, 88(2), 207.

Batool, B. F. (2013). Emotional intelligence and effective leadership. Journal of Business Studies Quarterly, 4(3), 84.

Blaskovics, B. (2014). Impact of leadership styles on project success-the case of a multinational company. Dynamic Relationships Management Journal, 3(2), 21-36.

Budur, T., \& Poturak, M. (2020). Transformational leadership and its impact on customer satisfaction. Measuring mediating effects of organisational citizenship behaviours. Middle East Journal of Management, 8(1), 67-91.

Chakrabortty, R. K., Sarker, R. A., \& Essam, D. L. (2017). Resource constrained project scheduling with uncertain activity durations. Computers \& Industrial Engineering, 112, 537-550.

Chaturvedi, S., Rizvi, I. A., \& Pasipanodya, E. T. (2019). How can leaders make their followers to commit to the organization? The importance of influence tactics. Global Business Review, 20(6), 1462-1474.

Conger, J. A. (1999). Charismatic and transformational leadership in organizations: An insider's perspective on these developing streams of research. The Leadership Quarterly, 10(2), 145-179.

Drucker, P. F. (2002). They're not employees, they're people. Harvard Business Review, 80(2), 70-77.

Dulewicz, V., \& Higgs, M. (2004). Can emotional intelligence be developed? The International Journal of Human Resource Management, 15(1), 95111.

Epstein, M. J., Buhovac, A. R., \& Yuthas, K. (2010). Implementing sustainability: The role of leadership and organizational culture. Strategic Finance, 91(10), 41.

Feyerherm, A. E., \& Rice, C. L. (2002). Emotional intelligence and team performance: The good, the bad and the ugly. International Journal of Organizational Analysis (1993-2002), 10(4).

Giritli, H., Öney-Yazıcı, E., Topçu-Oraz, G., \& Acar, E. (2013). The interplay between leadership and organizational culture in the Turkish construction sector. International Journal of Project Management, 31(2), 228-238.

Gottfredson, R. K., \& Aguinis, H. (2017). Leadership behaviors and follower performance: Deductive and inductive examination of theoretical rationales and underlying mechanisms. Journal of Organizational Behavior, 38(4), 558-591.

Gruden, N., \& Stare, A. (2018). The influence of behavioral competencies on project performance. Project Management Journal, $49(3)$, $98-109$.

Gündemir, S., Carton, A. M., \& Homan, A. C. (2019). The impact of organizational performance on the emergence of Asian American leaders. Journal of Applied Psychology, 104(1), 107.

Hair Jr, J. F. (1995). Multiple regression analysis. Multivariate Data Analysis with Readings.

Harper, M. G., \& Jones-Schenk, J. (2012). The emotional intelligence profile of successful staff nurses. The Journal of Continuing Education in Nursing, 43(8), 354-362.

Hiatt, J. (2006). ADKAR: a model for change in business, government, and our community. Prosci.

Hyväri, I. (2006). Success of projects in different organizational conditions. Project Management Journal, 37(4), 31-41. 
Jabbar, A. A., \& Hussein, A. M. (2017). The role of leadership in strategic management. International Journal of Research-Granthaalayah, 5(5), 99106.

Khator, A. A. (2012). The role of leadership in organizational development. International Journal of Business and Commerce, 1(11), 97-104.

MacGregor Burns, J. (1978). Leadership (First). New York: Harper \& Row, (C1978.

Macht, G. A., Nembhard, D. A., \& Leicht, R. M. (2019). Operationalizing emotional intelligence for team performance. International Journal of Industrial Ergonomics, 71, 57-63.

Mango, E. (2018). Rethinking leadership theories. Open Journal of Leadership, 7(01), 57.

Maqbool, R., Sudong, Y., Manzoor, N., \& Rashid, Y. (2017). The impact of emotional intelligence, project managers' competencies, and transformational leadership on project success: An empirical perspective. Project Management Journal, 48(3), 58-75.

Meng, X., \& Boyd, P. (2017). The role of the project manager in relationship management. International Journal of Project Management, 35(5), 717728.

Müller, R., \& Jugdev, K. (2012). Critical success factors in projects: Pinto, Slevin, and Prescott-the elucidation of project success. International Journal of Managing Projects in Business.

Raisiene, A. G. (2014). Leadership and managerial competences in a contemporary organization from the standpoint of Business Executives. Economics \& Sociology, 7(3), 179.

Ricketts, K. G. (2009). Behaving intelligently: Leadership traits \& characteristics. University of Kentucky College of Agriculture, Lexington .

Thompson, G., \& Glas $\varnothing$, L. (2018). Situational leadership theory: a test from a leader-follower congruence approach. Leadership \& Organization Development Journal.

Turner, R., \& Lloyd-Walker, B. (2008). Emotional intelligence (EI) capabilities training: can it develop EI in project teams? International Journal of Managing Projects in Business.

Zhang, G., Zhong, J., \& Ozer, M. (2020). Status threat and ethical leadership: A power-dependence perspective. Journal of Business Ethics, 161(3), $665-685$.

Zia-ur-Rehman, M., \& Zia, M. (2020). Framework Based Analysis of Corporate Leadership, Emotional Intelligence (EI) Competencies and Organizational Performance-A Developmental Perspective. Journal of Accounting and Finance in Emerging Economies, 6(2), 427-439.

Zuo, J., Zhao, X., Nguyen, Q. B. M., Ma, T., \& Gao, S. (2018). Soft skills of construction project management professionals and project success factors. Engineering, Construction and Architectural Management. 